\title{
A study on the predominant period of long-period ground motions in the Kanto Basin, Japan
}

\author{
Kazuo Yoshimoto* and Shunsuke Takemura
}

\begin{abstract}
We analyzed seismic waveforms of moderate to large shallow earthquakes recorded in the Kanto Basin, Japan, to clarify the characteristics of long-period ground motions in deep sedimentary basins. Our analysis revealed a tendency of long-period ground motions to develop in limited periods up to around $7 \mathrm{~s}$. In addition, we found a specific relation between the predominant period of long-period ground motions and the depth of bedrock. The predominant period tends to increase in proportion to bedrock depth until it reaches approximately $7 \mathrm{~s}$; however, it becomes almost constant for bedrock depths greater than $2 \mathrm{~km}$. These observations, in conjunction with numerical experiments performed in this study using realistic sedimentary basin structure models, indicate that the characteristic of long-period ground motions, excited by the basin-induced fundamental Love waves, is controlled strongly by the shallow sedimentary structure, if the bedrock depth exceeds approximately $2 \mathrm{~km}$. This result might also be important in understanding and evaluating the characteristics of long-period ground motions in other deep sedimentary basins of the world for moderate to large shallow earthquakes.
\end{abstract}

Keywords: Long-period ground motion; Predominant period; Sedimentary basin; Love wave; Kanto Basin

\section{Findings \\ Introduction}

In deep sedimentary basins, long-period ground motions induced by large-amplitude seismic surface waves might cause damage to large-scale constructions, such as high-rise buildings and oil storage tanks (e.g., Koketsu and Miyake 2008). Thus, it is necessary to study the characteristics of long-period ground motions in the corresponding areas for the purposes of estimation and mitigation of the damage from future destructive earthquakes. Since the analysis of velocity waveforms has been extensively carried out in these fields (e.g., Joyner 2000; Hatayama et al. 2004; Chen et al. 2012), we deal with long-period ground motions in terms of velocity waveforms in this study.

In past studies, the dependence of the predominant period of long-period ground motions on bedrock depth has been studied by assuming simple sedimentary layer structures (e.g., Kudo 1978). The conventional approach is effective and has advantages for calculation costs; however, a modeling using only few layers would be

\footnotetext{
* Correspondence: k_yoshi@yokohama-cu.ac.jp

Yokohama City University, 22-2 Seto, Kanazawa-ku, Yokohama 236-0027,

Japan
}

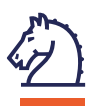

oversimplification of subsurface structure if the bedrock depth is deepened and the physical effects of the sedimentary structure on wave propagation become complex. In this study, we regard this effect as crucial for a deep understanding of the characteristics of the long-period ground motions in deep sedimentary basins and try to investigate the characteristics of the spatial variation of the predominant period in association with local sedimentary basin structure. We selected the Kanto Basin as the target basin because high-density seismic observation networks are deployed and the population density is very high.

Because seismic wave propagation in deep sedimentary basins might be sensitive to variations of seismic velocity with depth in the sediment, the characteristics of longperiod ground motions should be investigated based on realistic sedimentary structure models. In this study, using realistic sedimentary velocity models constructed from vertical seismic profiling (VSP) measurements, we discuss the reasons why the predominant period of long-period ground motions in deep sedimentary basins is limited to several seconds to around $7 \mathrm{~s}$ for moderate to large shallow earthquakes. 
(a)

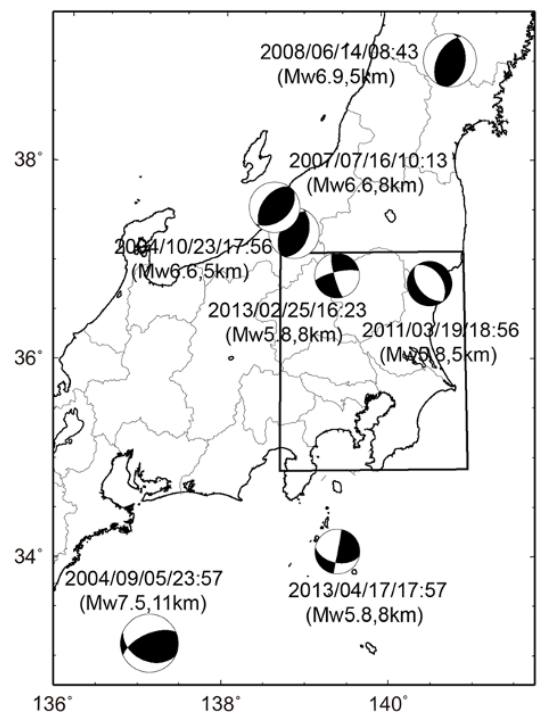

(b)

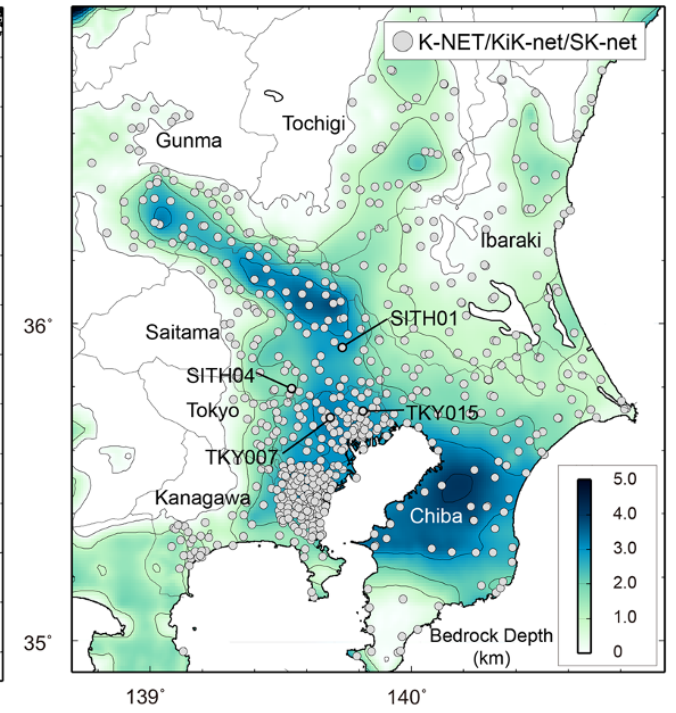

Figure 1 Map showing the locations of the earthquakes, Kanto Basin, and observation stations. (a) Locations and focal mechanisms of the seven earthquakes analyzed in this study. The rectangle indicates the enlarged area shown in (b). (b) Map showing the Kanto Basin and locations of seismic observation stations (gray circles). Local variation of bedrock depths (Koketsu et al. 2008) is illustrated by color gradations.

\section{Predominant period of long-period ground motions in} deep sedimentary basins

To investigate the characteristics of the predominant period of long-period ground motions in deep sedimentary basins, we analyzed the velocity seismograms from seven moderate to large shallow earthquakes (magnitude 5.8 to 7.5 ) that occurred around the Kanto Basin (Figure 1a). These earthquakes were selected to cover wide azimuthal distribution and provide sufficient data. The seismograms analyzed were collected from 664 stations of K-NET, KiK-net, and SK-net shown in Figure 1b.

As shown in Figure 1b, the depth of the bedrock locally exceeds $4 \mathrm{~km}$ in the Kanto Basin (Koketsu et al. 2008). The long-period ground motion induced by seismic surface waves is well observed in the central part of the

(a) $2004 / 10 / 23$ Event (2004 Mid-Niigata Earthquake)
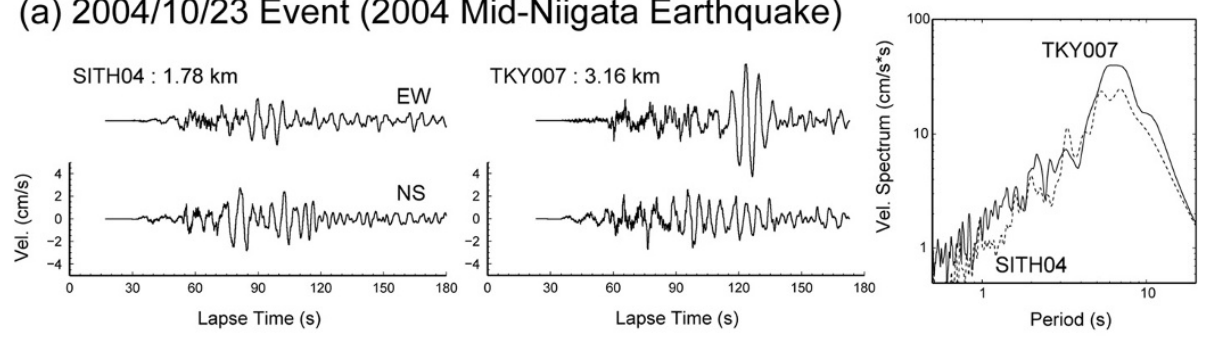

(b) 2008/06/14 Event (2008 Iwate-Miyagi Earthquake)
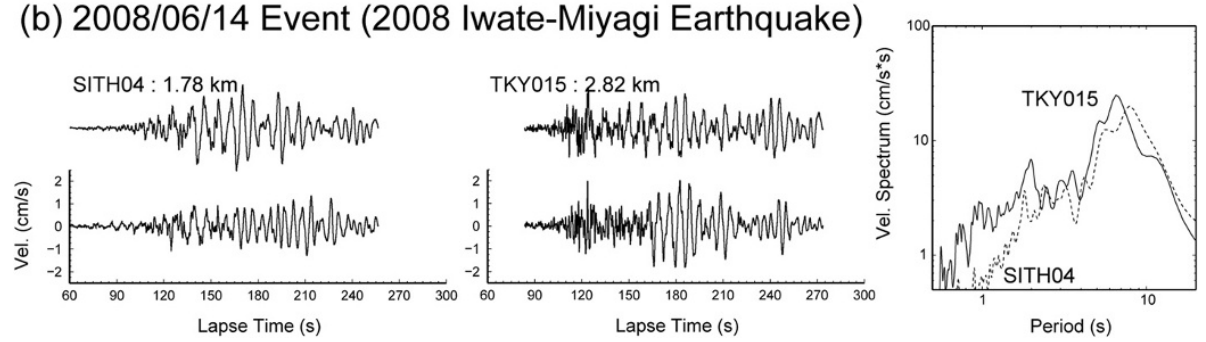

Figure 2 Examples of velocity seismograms and velocity spectra. (a) Velocity seismograms and velocity spectrum of horizontal ground motions recorded at SITH04 and TKY007 from the 2004 Mid-Niigata earthquake. The spectrum is calculated as the square root of the sum of the square of the NS and EW component spectral amplitudes. (b) Velocity seismograms and velocity spectrum of horizontal ground motions recorded at SITH04 and TKY015 from the 2008 Iwate-Miyagi earthquake. 
deep basin. Figure 2 shows an example of the seismograms recorded at three stations in the center of the Kanto Basin. After the onset of the short-period S waves, the large-amplitude long-period surface waves are clearly observed. A conventional Fourier spectrum analysis, using the horizontal velocity seismograms from the $150 \mathrm{~s}$ time window, including $\mathrm{S}$ and surface waves, reveals that the predominant periods of these surface waves are approximately $7 \mathrm{~s}$, as shown by the spectrum plots in the right of Figure 2. This result coincides with the analysis of surface waves (Love waves) of the 2004 Mid-Niigata earthquake by Furumura and Hayakawa (2007). Moreover, it is interesting to note that the predominant periods are almost identical among all stations, irrespective of the bedrock depth at the observation stations.

Figure 3 shows the dependence of the predominant period of long-period ground motions on the bedrock depth from four earthquakes, which provide a sufficient quantity of data and a wide azimuthal coverage. The same spectrum analysis as used in Figure 2 is applied to the horizontal velocity seismograms to estimate the dominant period at each station. The dominant period was searched over the period longer than $1 \mathrm{~s}$ to avoid the influence of high-frequency body waves. As for the three earthquakes located northwards from the Kanto Basin, the predominant period has a tendency to increase with the bedrock depth in the shallow part of the basin (<about $2 \mathrm{~km}$ ), whereas it is almost constant in the deeper part of the basin, even though there is a large scatter of data. In contrast, the observed predominant period is almost constant (approximately $7 \mathrm{~s}$ ) for the 2004 Southeast-Off Kii Peninsula earthquake located southwestward of the Kanto Basin, irrespective of the bedrock depth at the observation station. This finding might be explained by the propagation of large-amplitude
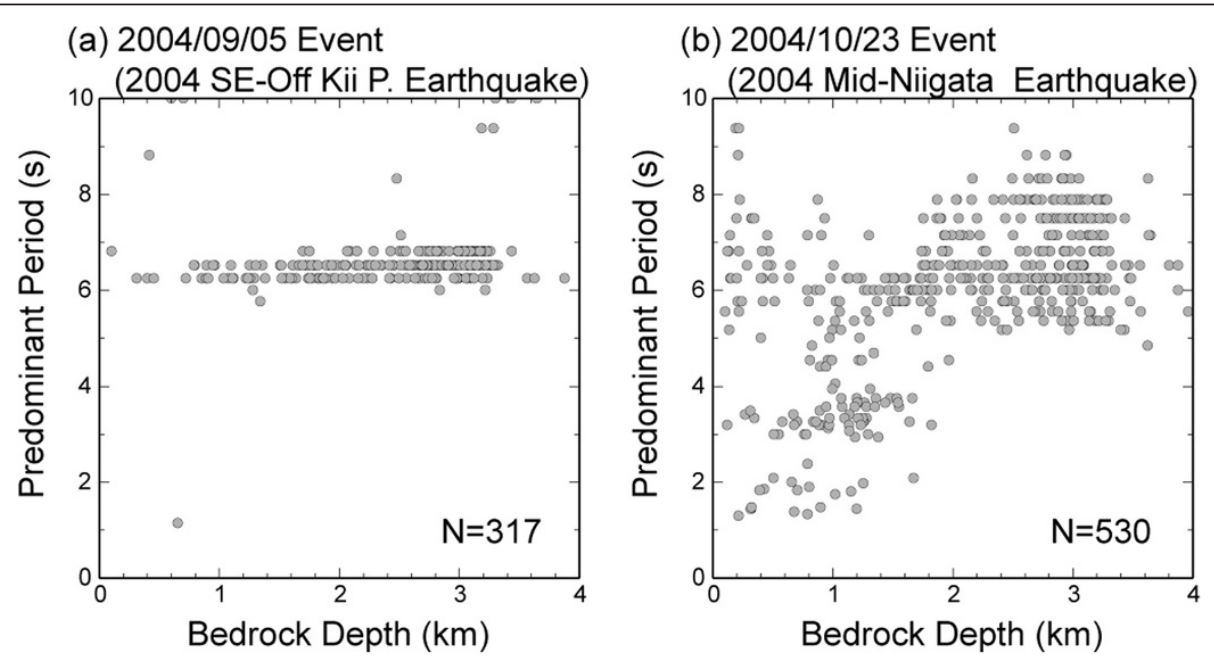

(c) $2008 / 06 / 14$ Event
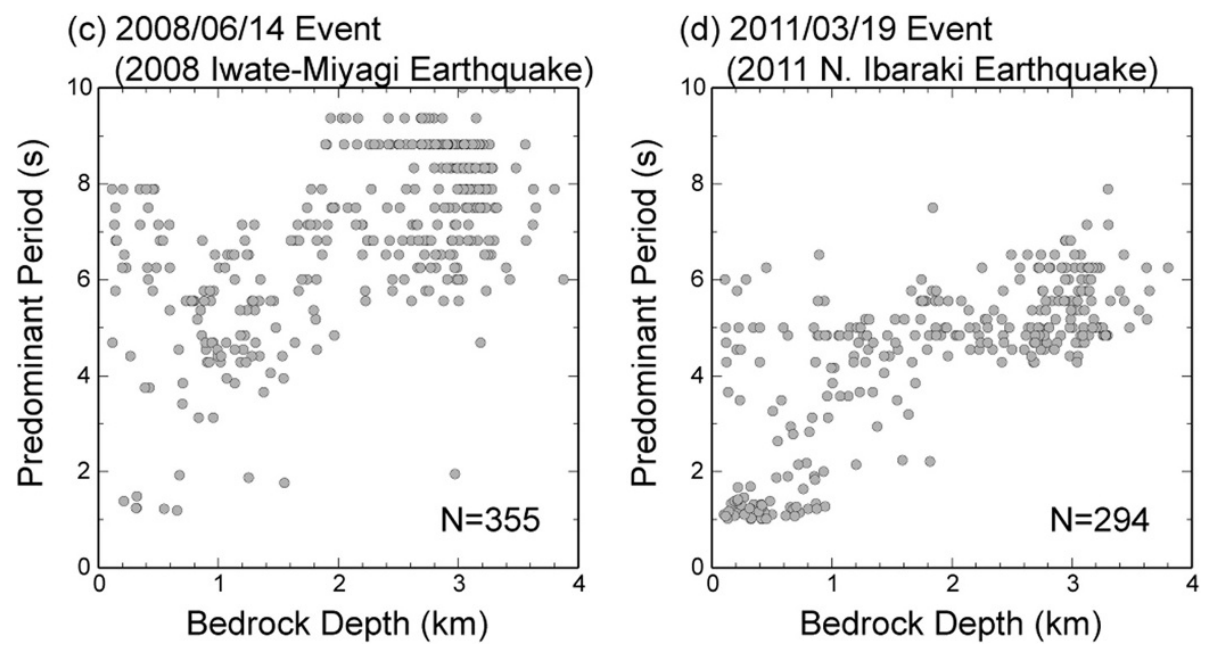

Figure 3 Comparison between the predominant period of long-period horizontal ground motion and bedrock depth. (a) 2004 Southeast-Off Kill Peninsula earthquake, (b) 2004 Mid-Niigata earthquake, (c) 2008 Iwate-Miyagi earthquake, and (d) 2011 north Ibaraki earthquake. The number of data is shown at the lower right of the each figure. 
surface waves excited and developed by the low-velocity seafloor sediments of the Pacific Ocean (Miyake and Koketsu 2005).

To examine the statistical relationship between the bedrock depth and the predominant period of observed long-period ground motions, we calculated probability density function (PDF) of predominant period at an interval of $0.1 \mathrm{~km}$ in bedrock depth. Figure 4 shows the estimated PDF of predominant period as a function of the bedrock depth. As seen in Figure 3, the predominant period (high-probability-density area in Figure 4) shows a tendency to increase with bedrock depth in the shallow part of the basin $(<$ about $2 \mathrm{~km}$ ), whereas it is almost constant (approximately $7 \mathrm{~s}$ ) in the deeper part of the basin. Although there is a large scatter of data, this observation implies that the physical effect of the bedrock on long-period ground motions is sufficiently strong to be observable in the shallow part of the basin, but it becomes very weak where the depth of the bedrock exceeds about $2 \mathrm{~km}$.

Long-period ground motion is characterized by the effects of the source, path, and local site (e.g., Joyner 2000). In relation to this, our observational results, which are obtained from seven earthquakes having different hypocenter distances and wide azimuthal coverage, confirm that the local site effect is an important factor to characterize the predominant period of longperiod ground motions in the Kanto Basin. Thus, we focus our attention to the effect of the local site structure on surface wave excitation.

\section{Seismic velocity structure of the sediment and surface wave modes}

The seismic velocity structure of the Kanto Basin has been investigated by many researchers using a variety of geophysical techniques, such as seismic refraction experiments, H/V spectral ratio analysis, and microtremor array exploration (e.g., Koketsu and Higashi 1992; Sato and Higashi 2006; Yamanaka and Yamada 2006). In addition, limited numbers of VSP measurements at deep boreholes (deeper than $1 \mathrm{~km}$ ) have revealed very accurate in situ seismic velocity structures (Yamamizu 1996, 2004). Assembling the results from 14 VSP measurements, Yoshimoto and Takemura (2014) indicated that the depth variation of seismic velocity of the sediment in the Kanto Basin could be modeled satisfactorily by the exponential asymptotically bounded velocity function (Ravve and Koren 2006) in the first-order approximation. It is worth noting that at most of the VSP measurement points, the S-wave velocity shows a continuous increase with depth from $0.5 \mathrm{~km} / \mathrm{s}$ or less at the free surface to about $2 \mathrm{~km} / \mathrm{s}$ at depths of $1.5 \mathrm{~km}$ (Yoshimoto and Takemura 2014).

Figure 5a shows a seismic velocity structure model of the SITH01 at Iwatsuki (see Figure 1b), which is located in the mid-northern part of the Kanto Basin (Yoshimoto and Takemura 2014). The bedrock depth of $2.8 \mathrm{~km}$ at this site is a representative value for the middle part of the Kanto Basin (see Figure 1b). We calculated the medium response (Harkrider 1964) for this 1D structure model to discuss the period-amplitude relationship of
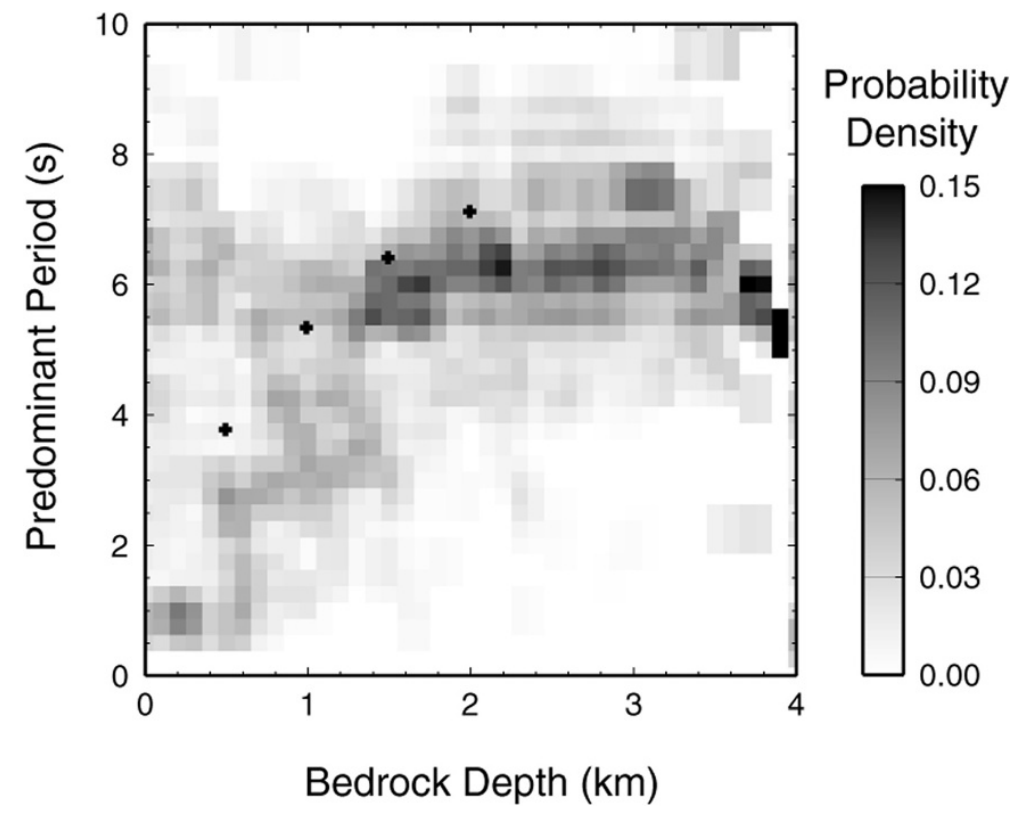

Figure 4 Relationship between bedrock depth and predominant period of long-period horizontal ground motion. Probability density plot was estimated from 2032 data of the seven earthquakes analyzed in this study. The cross indicates the theoretical prediction from the 1D model analysis shown in Figure 6. 


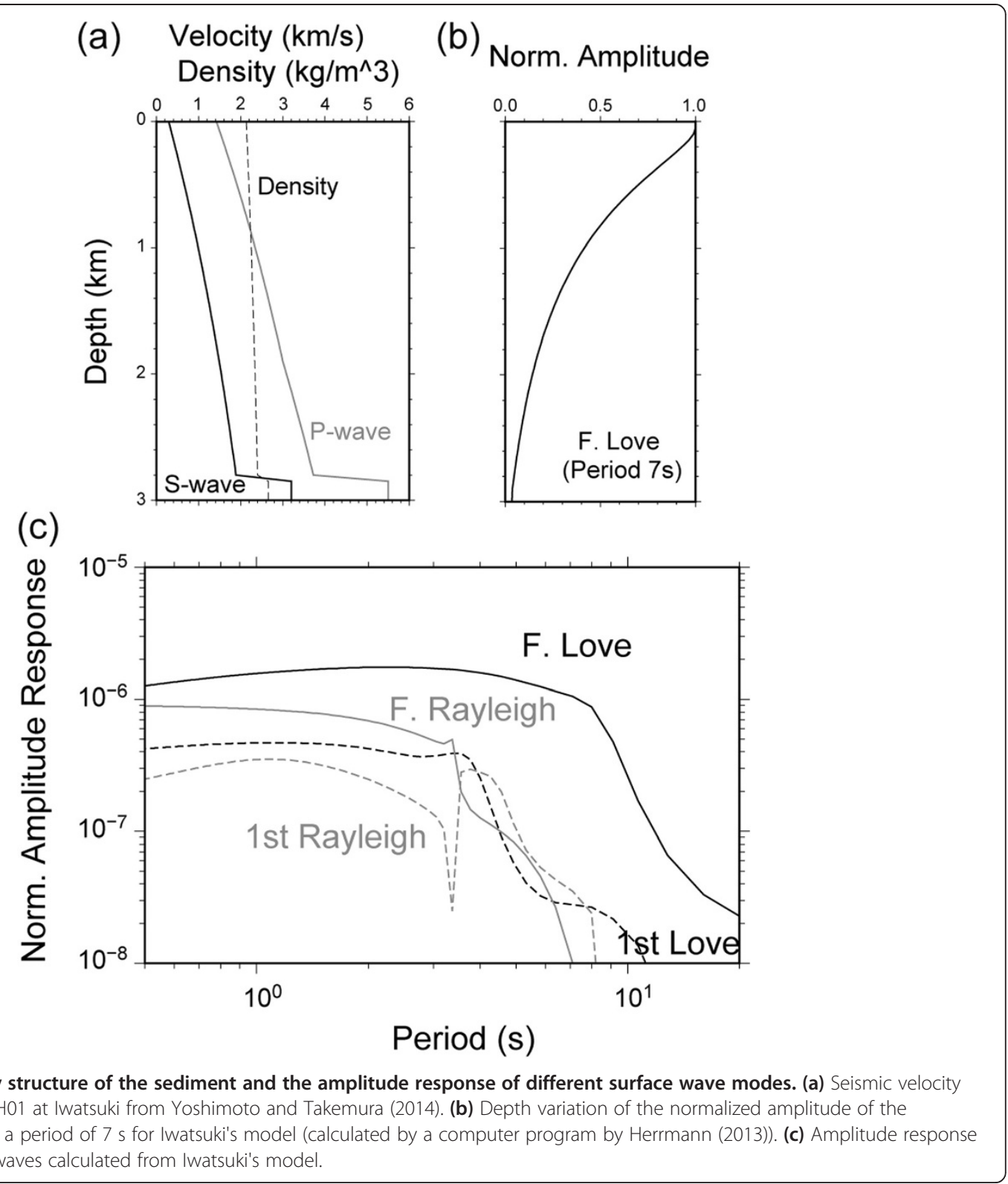

the basin-induced Love and Rayleigh waves (hereafter, we call 'medium response/wavenumber' the amplitude response for estimating the strength of surface wave excitation). Figure $5 \mathrm{c}$ shows the tendency for Love waves to dominate the Rayleigh waves in this structure, and the fundamental Love waves would be the most dominant surface waves. This result is consistent with the observations of distinct Love wave excitations in the Kanto Basin (e.g., Yamazaki et al. 1992; Kato et al. 1993). An intriguing feature of the amplitude response shown in Figure 5c is the sharp cutoff of its amplitude above about $10 \mathrm{~s}$, indicating that the Love wave excitation becomes less effective for periods above $10 \mathrm{~s}$.

\section{Discussion and conclusion}

As seen in Figure 4, it is evident that the predominant period of long-period ground motion is affected by the bedrock depth of the sedimentary basin. A similar observation has been reported for the Osaka sedimentary basin, western Japan (Miyakoshi and Horike 2006). Hence, it might be meaningful to investigate the relationship between the amplitude response of fundamental Love waves and the bedrock depth by modifying Iwatsuki's structure model, which shows a standard characteristic of the sediment of the Kanto Basin (Yoshimoto and Takemura 2014).

Figure 6 shows the amplitude response of the fundamental Love wave calculated for different bedrock depths 


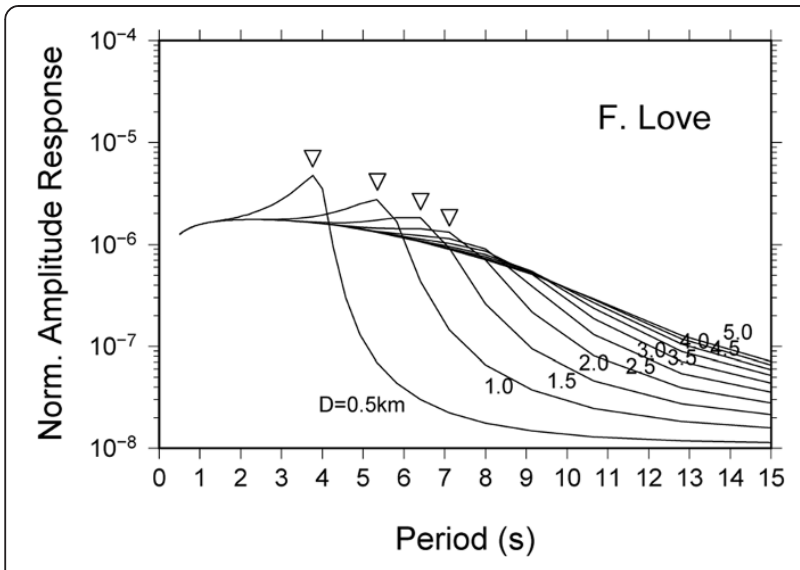

Figure 6 Amplitude response of the fundamental Love wave for the seismic velocity structure models with different bedrock depths. Iwatsuki's structure model is used in the calculation as a reference structure model. The inverted triangles indicate the peak of the amplitude response.

up to $5 \mathrm{~km}$ in intervals of $0.5 \mathrm{~km}$, where the deep structure for the calculation is constructed from the Japan Integrated Velocity Structure Model by Koketsu et al. (2008). As can be seen in this figure, the amplitude response shows a clear peak for shallow bedrock depths (<about $2 \mathrm{~km}$ ), indicating the strong excitation of the fundamental Love waves at this peak period. In contrast, the excitation is shown to become very weak at longer periods by the steep fall-off of the amplitude response above the peak period. The flattening of the amplitude response in the short periods is due to the upward bending of seismic rays in the sediment with vertical velocity gradient. It is also interesting that the shape of the amplitude response is similar among the different structure models for deep bedrock depths. This result indicates that the excitation of the basin-induced fundamental Love wave is strongly characterized by the shallow sedimentary velocity structure, irrespective of the bedrock depth. The illustration of the depth variation of long-period Love wave amplitude in Figure 5b might be suggestive of the weak physical effect of the bedrock on the excitation of long-period Love waves.

We overlay the theoretical prediction for the fundamental Love wave excitation discussed above on Figure 4 (cross in the figure) to compare it with the observation. The theoretical prediction explains well the observed relationship between bedrock depth and the predominant period of long-period ground motions for shallow bedrock depths (<about $2 \mathrm{~km}$ ), except for a slight overestimation. This result might indicate the effective excitation of Love waves in the basin edge area (e.g., Kinoshita et al. 1992). One possible cause for the overestimation is the 3D geometrical effect of the Kanto Basin, which has not been taken into account in our theoretical consideration. As the
Kanto Basin has a 3D shape in which the bedrock depth increases towards the center, it is likely that the observed Love waves at a certain station show the excitation effect from shallower parts of the basin if the incident wave for the Love wave excitation comes from outside the basin. A dipping bedrock interface might enhance the trapping of the incident wave energy in the sediment; thus, exciting the surface waves more effectively (e.g., Frankel 1993). However, we do not discuss this effect in detail in this paper.

There are seismic observations from the Kanto Basin reporting the predominant period of long-period ground motions longer than $10 \mathrm{~s}$ (e.g., Tanaka et al. 1979). In this paper, we noted the observation that the predominant period of long-period ground motion of moderate to large shallow earthquakes has the tendency to become almost constant (approximately $7 \mathrm{~s}$ ) in the Kanto Basin. However, as for the large to great shallow earthquakes at local to regional distances, we should expect long-period ground motions with predominant periods longer than $10 \mathrm{~s}$, in relation to the source spectrum having very rich energy in the long period. It is appropriate to leave the quantitative research on this topic for a future study.

In this paper, we reported the observation that the predominant period of long-period ground motion of moderate to large earthquakes shows the tendency to increase with bedrock depth in the shallow parts of the basin, whereas it is almost constant in the deeper parts of the basin. By using realistic sedimentary structure models and conventional surface wave theory, this observation was interpreted as indicating that the shallow velocity structure at less than about $2 \mathrm{~km}$ depth plays an important role in the excitation of basin-induced Love waves in the deep sedimentary basins. This perception and the associated seismic investigations could be very important in the evaluation of the development of surface waves, not only in deep sedimentary basins in land areas, but also in thick accretionary prisms in marine areas throughout the world.

\section{Competing interests}

The authors declare that they have no competing interests.

\section{Authors' contributions}

KY carried out theoretical consideration on seismic response of the sedimentary structure of the Kanto Basin and drafted the manuscript. ST conducted waveform analysis and helped draft the manuscript. Both authors read and approved the final manuscript.

\section{Acknowledgements}

The authors acknowledge the National Research Institute for Earth Science and Disaster Prevention, Japan, for the K-NET and KiK-net data, and the Earthquake Research Institute, University of Tokyo for the SK-net data. The authors would like to thank Dr. R. B. Herrmann and Dr. Y. Hisada for providing the computer program for the surface wave analysis. We also thank two anonymous reviewers for their thoughtful reviews of this article. Some figures in this article were drawn using the Generic Mapping Tools software package. 
Received: 30 January 2014 Accepted: 19 August 2014

Published: 26 August 2014

\section{References}

Chen KC, Wang JH, Huang BS, Liu CC, Huang WG (2012) Vibrations of the TAIPEI 101 skyscraper caused by the 2011 Tohoku earthquake, Japan. Earth Planets Space 64:1277-1286

Frankel A (1993) Three-dimensional simulations of ground motions in the San Bernardino Valley, California, for hypothetical earthquakes on the San Andreas Fault. Bull Seismol Soc Am 83:1020-1041

Furumura T, Hayakawa T (2007) Anomalous propagation of long-period ground motions recorded in Tokyo during the 23 October $2004 M_{w} 6.6$ Niigata-ken Chuetsu, Japan, Earthquake. Bull Seismol Soc Am 97:863-880, doi:10.1785/ 0120060166

Harkrider DG (1964) Surface waves in multilayered elastic media I. Rayleigh and Love waves from buried sources in a multilayered elastic half-space. Bull Seismol Soc Am 54:627-679

Hatayama K, Zama S, Nishi H, Yamada M, Hirokawa Y, Inoue R (2004) Long-period strong ground motion and damage to oil storage tanks due to the 2003 Tokachi-oki earthquake (in Japanese with English abstract). J Seismol Soc Jpn 57:83-103

Herrmann RB (2013) Computer programs in seismology: an evolving tool for instruction and research. Seismol Res Lett 84:1081-1088, doi:10.1785/ 0220110096

Joyner WB (2000) Strong motion from surface waves in deep sedimentary basins. Bull Seismol Soc Am 90:S95-S112

Kato K, Aki K, Teng TL (1993) 3-D simulations of surface wave propagation in the Kanto sedimentary basin, Japan, Part 1: application of the surface wave Gaussian beam method. Bull Seismol Soc Am 83:1676-1699

Kinoshita S, Fujiwara H, Mikoshiba T, Hoshino T (1992) Secondary Love waves observed by a strong-motion array in the Tokyo lowlands, Japan. J Phys Earth 40:99-116

Koketsu K, Higashi S (1992) Three-dimensional topography of the sediment/ basement interface in the Tokyo Metropolitan area, central Japan. Bull Seismol Soc Am 82:2328-2349

Koketsu K, Miyake H (2008) A seismological overview of long-period ground motion. J Seismol 12:133-143, doi:10.1007/s10950-007-9080-0

Koketsu K, Miyake H, Fujiwara H, Hashimoto T (2008) Progress towards a Japan integrated velocity structure model and long-period ground motion hazard map. In: Proceedings of the 14th world conference on earthquake engineering, Beijing, 12-17 Oct 2008, Paper No. S10-038

Kudo K (1978) The contribution of Love waves to strong ground motions. Proc 2nd Inter Conf on Microzonation 2:765-776

Miyake H, Koketsu K (2005) Long-period ground motions from a large offshore earthquake: the case of the 2004 off the Kii peninsula earthquake, Japan. Earth Planets Space 57:203-207

Miyakoshi K, Horike M (2006) Predominant period of the long-period ground motions in the Osaka basin (in Japanese with English abstract). BUTSURITANSA 59:327-336

Ravve I, Koren Z (2006) Exponential asymptotically bounded velocity model: part I - effective models and velocity transformations. Geophysics 71:T35-T65, doi:10.1190/1.2196033

Sato H, Higashi S (2006) 3D subsurface structural model for long-period ground motion simulation around Kanto plain, Japan. Civil Engineering Research Laboratory Rep No.N05059, Central Research Institute of Electric Power Industry, Tokyo

Tanaka T, Yoshizawa S, Osawa Y (1979) Characteristics of strong earthquake ground motion in the period range from 1 to 15 seconds-analysis of the low-magnification seismograph records. Bull Earthquake Res Inst Univ Tokyo 54:629-655 (in Japanese with English abstract)

Yamamizu F (1996) Down-hole measurements of seismic wave velocities in deep soil deposits beneath the Tokyo metropolitan area. In: Report of the National Research Institute for Earth Science and Disaster Prevention 56, NIED, Tsukuba, pp 1-32

Yamamizu F (2004) Seismic wave velocity structures in Kanto area as revealed by the crustal activity observation well VSP (in Japanese with English abstract). Technical Note of the National Research Institute for Earth Science and Disaster Prevention 251:1-75
Yamanaka H, Yamada N (2006) Estimation of 3D S-wave velocity model of the Kanto basin, Japan, using Rayleigh wave phase velocity. Bull Earthquake Res Inst Univ Tokyo 81:295-301

Yamazaki K, Minamishima M, Kudo K (1992) Propagation characteristics of intermediate-period (1-10 seconds) surface waves in the Kanto plain, Japan. J Phys Earth 40:117-136

Yoshimoto K, Takemura S (2014) Surface wave excitation at the northern edge of the Kanto Basin, Japan. Earth Planets Space 66:16, doi:10.1186/1880-5981-66-16

doi:10.1186/1880-5981-66-100

Cite this article as: Yoshimoto and Takemura: A study on the predominant period of long-period ground motions in the Kanto Basin Japan. Earth, Planets and Space 2014 66:100.

\section{Submit your manuscript to a SpringerOpen ${ }^{\odot}$ journal and benefit from:}

- Convenient online submission

- Rigorous peer review

- Immediate publication on acceptance

- Open access: articles freely available online

- High visibility within the field

- Retaining the copyright to your article

Submit your next manuscript at $>$ springeropen.com 